\title{
Rethinking International Relations
}




\section{By the same author}

Arabia without Sultans

Iran: Dictatorship and Development

Threat from the East? Soviet Policy in the Age of Crisis

The Ethiopian Revolution (co-author)

The Making of the Second Cold War

State and Ideology in the Middle East and Pakistan (co-editor)

Cold War, Third World

Revolution and Foreign Policy: The Case of South Yemen, 1967-1987

Arabs in Exile: Yemeni Migrants in Urban Britain 


\title{
Rethinking International Relations
}

\author{
Fred Halliday
}

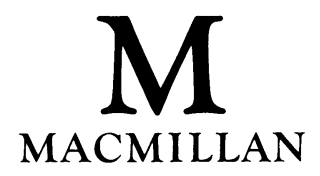


(C) Fred Halliday 1994

All rights reserved. No reproduction, copy or transmission of this publication may be made without written permission.

No paragraph of this publication may be reproduced, copied or transmitted save with written permission or in accordance with the provisions of the Copyright, Designs and Patents Act 1988, or under the terms of any licence permitting limited copying issued by the Copyright Licensing Agency, 90 Tottenham Court Road, London W1P 9HE.

Any person who does any unauthorised act in relation to this publication may be liable to criminal prosecution and civil claims for damages.

First published 1994 by

THE MACMILLAN PRESS LTD

Houndmills, Basingstoke, Hampshire RG21 2XS

and London

Companies and representatives

throughout the world

ISBN 978-0-333-58905-2

ISBN 978-1-349-23658-9 (eBook)

DOI 10.1007/978-1-349-23658-9

A catalogue record for this book is available from the British Library. 


\section{Contents}

Acknowledgements

viii

Preface

1 Introduction: The Pertinence of the 'International' 1

The 'International' in Perspective 1

Formative Influences 4

The Emergence of Theory 5

Realism and Behaviouralism $\quad 10$

International Relations since the 1970s 16

The Parameters of 'Rethinking' 19

2 Theories in Contention 23

Traditional Empiricism: History and the English School 24

'Scientific Empiricism': the Siren of Behaviouralism 27

Neo-Realism: 'System' without Content 31

The Tallest Story: Post-modernism and the International 37

Conclusion: Another Path 46

3 A Necessary Encounter: Historical Materialism and International Relations $\quad 47$

A Challenge Evaded $\quad 47$

Marxism and IR's Three 'Great Debates' $\quad 50$

The Potential of Historical Materialism 55

The Historical Materialist Paradigm $\quad 59$

The Inhibitions of Theory $\quad 68$

Marxism beyond Cold War $\quad 71$

4 State and Society in International Relations $\quad 74$

Impasse on the State $\quad 74$

Definitions Contrasted $\quad 78$

The State as Domestic and International Actor $\quad 84$

State Interests and Social Forces $\quad 86$

$\begin{array}{ll}\text { Societies and State Systems } & 87\end{array}$ 
5 International Society as Homogeneity $\quad 94$

The Meanings of 'International Society' 94

Transnationalism and its Limits 103

The 'Constitutive' Paradigm and its Protagonists: Burke, Marx, Fukuyama 107

Implications for International Relations

6 'The Sixth Great Power': Revolutions and the International System

A Case of Mutual Neglect 124

Revolutions and their Effects 128

The Formation of the International System 132

Historical Patterns 134

International and Domestic Links $\quad 139$

Revolutions and War 143

7 Hidden from International Relations: Women and the International Arena $\quad 147$

The Silences of International Relations 147

An Emerging Concern: Four Dimensions 152

State and Women: Nationalism and Human Rights $\quad 160$

Implications and Problems 166

8 Inter-Systemic Conflict: The Case of Cold War 170

A Distinct Form of Conflict 170

Theories of Cold War 171

Sources of Theoretical Resistance 177

The Salience of Heterogeneity 180

9 A Singular Collapse: The Soviet Union and Inter-State Competition 191

New Light on Old Questions $\quad 191$

Transformation from Above 192

The Transition from Socialism to Capitalism 195

International Factors and Cold War 198

A Comparative Failure 205

Three Levels of International Competition 211 
10 International Relations and the 'End of History'

Aftermaths of Cold War

Varieties of Historical Evaluation

The 'End of History'

228

Prospects for Liberal Democracy and Peace

11 Conclusion: The Future of International Relations

Notes

Name Index 


\section{Acknowledgements}

The author and publishers are grateful to the following for permission to reproduce copyright material: Routledge Journals and the editors of Economy and Society; the editors of Millennium, The Journal of International Studies; Cambridge University Press; the editors of New Left Review; Blackwell Publishers and the editors of Political Studies; and the editors of the Review of International Studies. 


\section{Preface}

The chapters in this book are elements of a double response - to developments in political and social theory and in the academic study of International Relations, and to changes in the international system itself over the past years, most particularly the collapse of the Soviet bloc. In this sense, and in what may be a reversal of conventional practice, the general, and in part theoretical, reflections follow from a number of more concrete studies of the international system and of the central conflicts within it which I have already published, most specifically The Making of the Second Cold War (1983) and Cold War, Third World (1989) and a number of third world case studies. In so doing, I hope not merely to extend these reflections on International Relations, but also to draw out assumptions and questions which were, to a greater or lesser extent, present within them. International Relations, like all branches of knowledge, faces two dangers - that of factual accounts devoid of theoretical reflection, explanatory or ethical, and that of theorising unanchored in, or tested by, the analysis of history itself. My hope is that these essays, as responses to ideas and to events, will find a passage between these two dangers. While making some general observations on the nature of the international system and of where analysis of it may proceed, I have also examined some more particular issues. My intention is to follow this overview of the subject with two further theoretical and historical volumes, one on the role of revolutions in the international system, the other on the ethical tension between nationalism and internationalism.

In preparing these essays I have benefited from the stimulation and criticism of many friends and colleagues over the past decade. In particular I would like to thank my colleagues and students in the International Relations (IR) Department at the London School of Economics (LSE) who have, through individual contacts and through the General Seminar in IR, provided many a challenge and stimulus. Martina Langer of the International Relations Department was ever helpful and speedy in helping with 
preparation of the text. I would also like to thank the members of the '1990s' International Relations discussion group, and of the Transnational Institute, for providing congenial intellectual contexts for the working through of many of these ideas. My greatest thanks are to my partner, Maxine Molyneux, whose support and ideas have been as enriching as they have been indispensable.

While the chapters of this book have been updated and considerably developed, many of the ideas and arguments contained in this book draw on a set of articles and essays published over the last few years: in particular parts of Chapters 1 and 2 have appeared in Political Studies (vol. 38, no. 3, September 1990), Economy and Society (vol. 18, no. 3 August 1989) and Millennium (vol. 22, no. 2, summer 1993); an earlier version of Chapter 4 was published in Millennium (vol. 16, no. 2, 1987); of Chapter 5 in Millennium (vol. 21, no. 3, winter 1992); of Chapter 6 in Review of International Studies (vol. 16, no. 3, summer 1990); of Chapter 7 in Millennium (vol. 17, no. 3, winter 1988); of Chapter 8 in Mike Bowker and Robin Brown (eds.) From Cold War to Collapse: Theory and World Politics in the 1980s (Cambridge University Press, 1993); of Chapter 9 in Contention (no. 2, winter 1992). Chapters 10 and 11 include material from New Left Review (no. 193, May-June 1992) and from the Barclay Enterprise Lecture, given at LSE, 17 May 1993, 'Sleep-Walking Through History: The New World and its Discontents', later published by the London School of Economics Centre for the Study of Global Governance. 